\title{
Parvovirus associated antigen in the synovial membrane of patients with rheumatoid arthritis
}

\author{
G STIERLE, ${ }^{1} \mathrm{~K}$ A BROWN, ${ }^{1}$ S G RAINSFORD. ${ }^{1}$ C A SMITH, 2 \\ D HAMERMAN, ${ }^{2}$ H E STIERLE, ${ }^{3}$ AND D C DUMONDE
}

From the ${ }^{1}$ Department of Immunology, United Medical and Dental Schools, St Thomas's Campus, London; the ${ }^{2}$ Department of Medicine, Montefiore Hospital, Albert Einstein College of Medicine, Bronx, New York; and the ${ }^{3}$ Medizinische Abteilung, Krankenhaus der Barmherzigen Brüder, D-5599 Trier, W Germany

SUMmARY Homogenates of synovium from patients with rheumatoid arthritis (RA) and osteoarthritis (OA) were centrifuged on caesium chloride density gradients to obtain isolates of a density similar to that of parvoviruses. Six of $11 \mathrm{RA}$ isolates and none of six OA isolates reacted with an antiserum raised against a rheumatoid associated, parvovirus-like agent (RA-1 virus). An anti-B19 parvovirus antiserum did not react with any of the isolates tested. Electron microscopy of negatively stained preparations of the isolates showed that small particles of diameter $10 \mathrm{~nm}$ were abundant in most of the RA isolates (11/13) but absent from all OA isolates. Such particles, whose identification is unknown, were also present in RA-1 positive lysates prepared from cultured RA synovial cells. These results suggest that the RA-1 virus can be directly identified in RA synovial tissue and that the virus appears to be unrelated to the human B19 parvovirus.

Key words: viruses, RA-1 virus, joints.

A group of workers in the USA recently summarised their findings relating to the identification of a parvovirus-like agent in rheumatoid synovium. ${ }^{1}$ By long term coculture of rheumatoid synovial cells with human lung fibroblasts or fetal rabbit synovial cells they obtained an infectious agent which, depending on the route of administration, induced fatal encephalopathy or runting, limb deformities, and kyphoscoliosis in young mice. Such effects were not seen when using synovial cells from patients with osteoarthritis (OA). Although the infectious agent, termed the RA-1 virus, resembled parvovirus in size (24-25 nm) and physicochemical properties, it did not react with antisera to several known human and animal parvoviruses. A neutralising antiserum (antiRA-1 antiserum) raised against the RA-1 virus reacted with other rheumatoid isolates but not with any of the animal parvoviruses tested.' Additional studies have shown the virus to be present in RA synovial cells when harvested directly from culture. ${ }^{2}$ The implication that parvovirus may have some bearing on the initiation or perpetuation of rheumatoid disease has stimulated a number of workers to search for a possible association between parvovirus

Accepted for publication 1 October 1986.

Correspondence to Dr K A Brown. Department of Immunology, The Rayne Institute, St Thomas's Hospital, London SE1 7EH. infection and arthropathy. An association of arthritis with an outbreak of erythema infectiosum induced by the B19 parvovirus has recently been described, ${ }^{3}$ together with a report suggesting evidence of a prevalence of recent B19 virus infections in patients attending an early synovitis clinic. ${ }^{4}$

The aim of the present study was to determine if parvovirus-like particles could be identified in caesium chloride fractions of homogenised rheumatoid synovia prepared at a density similar to that of infective parvovirus $(1.38 \mathrm{~g} / \mathrm{ml})^{5}$ and whether such fractions were reactive with the anti-RA-1 antiserum and antibodies directed against the B19 virus.

\section{Patients and methods}

PATIENTS

Synovial membranes were obtained from 13 patients with RA (mean age 59 years) and eight patients with OA (mean age 64 years) who were undergoing total knee or hip replacements. All of the rheumatoid patients fulfilled the American Rheumatism Association criteria of definite or classical rheumatoid arthritis, ${ }^{6}$ and six of the 13 sera were seropositive for rheumatoid factor. Synovial cell cultures of an additional three patients with RA and two with OA were obtained from New York. 
EXPERIMENTA L PROCEDURE

The sequence of experimental steps is outlined in Fig. 1.

Synovial membrane or synovial membrane derived cell
cultures, or both
Fluorocarbon extraction, ammonium sulphate pre-
cipitation, centrifugation through caesium chloride
cushion (density $1.38 \mathrm{~g} / \mathrm{ml}$ )
Analysis of the pellet (isolated) by:
(a) EM (negative staining)
(b) CIE anti-B19 virus antibody
(c) RIA $\}$ anti-RA-1 antibody
(d) ELISA and

Fig. 1 Experimental procedure. $(E M=$ electron microscopy, $C I E=$ counterimmunoelectrophoresis; $R I A=$ radioimmunoassay; $E L I S A=$ enzyme linked immunosorbent assay.)

ISOLATION OF VIRUS-LIKE PARTICLES FROM SYNOVIAL TISSUE

Synovial membrane which had been dissected free from underlying tissues was homogenised to $20 \%$ suspension in phosphate buffered saline and frozen and thawed on three occasions. This step was followed by a fluorocarbon extraction. The suspension was mixed with fluorocarbon at one third of its volume, homogenised, and centrifuged at $7000 \mathrm{~g}$ for one hour. The proteins within the supernatant were precipated by $50 \%$ saturated ammonium sulphate, dialysed against $0.9 \%$ saline, and layered onto a caesium chloride cushion of density $1.38 \mathrm{~g} / \mathrm{ml}$. After centrifugation for 16 hours at $16000 \mathrm{~g}$ the pellet was resuspended in saline and subsequently referred to as the isolate.

PREPARATION OF SYNOVIAL CELL CULTURES The method was similar to that described by Dayer et $a .^{7}$ Synovial tissue obtained within two hours of surgery was washed in Dulbecco's modified Eagle's medium (DMEM) containing penicillin $(100$ units $/ \mathrm{ml})$ and streptomycin $(100 \mathrm{mg} / \mathrm{ml})$, buffered to $\mathrm{pH} 7 \cdot 3$ with $20 \mathrm{mM}$ HEPES $(N-2$-hydroxyethylpiperazine- $N^{\prime}$-2-ethanesulphonic acid). Superficial synovial layers were dissected free from the underlying tissue and small fragments of synovium (1-2 $\mathrm{mm}^{3}$ ) incubated in $10 \mathrm{ml}$ collagenase solution (type I, 125-200 units $/ \mathrm{mg} / \mathrm{ml}$ DMEM) for three hours at $37^{\circ} \mathrm{C}$. The suspension was then treated with $10 \mathrm{ml}$ trypsin-ethylenediaminetetraacetic acid solution $(0.5 \mathrm{~g}$ trypsin and $2.0 \mathrm{~g}$ EDTA/l; modified Pucks saline A) and the incubation extended for another hour. Isolated cells, removed from undigested fragments, were washed twice with DMEM and seeded into tissue culture flasks at $\mathrm{a} \underset{\vec{F}}{\vec{F}}$ concentration of $1-4 \times 10^{5}$ viable cells $/ \mathrm{ml}$. The flasks were incubated overnight at $37^{\circ} \mathrm{C}$ in an atmosphere $\frac{\mathrm{C}}{\mathrm{O}}$ of $5 \% \mathrm{CO}_{2}$ in air. Non-adherent cells were removed $\frac{\bar{c}}{\mathrm{c}}$ by washing and the adherent cells maintained in $\overrightarrow{\widetilde{\sigma}}$ DMEM supplemented with $10 \%$ heat inactivated $\varrho$ fetal calf serum.

ELECTRON MICROSCOPY (EM)

Ultrathin sections of the synovial membranes were $\vec{\omega}$ performed in the neurovirology department, St Thomas's hospital. For negative staining $5 \mu \mathrm{l}$ of the $\overline{0}$ isolates was applied to a copper grid and stained $\vec{\sigma}$ with $2 \%$ phosphotungstic acid, $\mathrm{pH} 7 \cdot 0$.

ASSAYS FOR THE DETECTION OF B19 VIRUS $\overrightarrow{0}$ Two assays were used: (a) countercurrent im-음 munoelectrophoresis (CIE) was performed in $1 \%-$ agarose buffered with barbitone, $\mathrm{pH} 8 \cdot 2$, according 3 to standard techniques. The antibody (anti-B19) and $\frac{3}{\circ}$ the antigen positive control were kindly donated by Dr B Cohen, Colindale; $(b)$ radioimmunoassay $\vec{\odot}$ (RIA) was performed in Dr Cohen's laboratory.. (Virus Reference Laboratory, Colindale, UK) using a monoclonal antibody directed against the human parvovirus B19. PREPARATION OF ANTI-RA-1 ANTISERA
Rabbits were immunised with detergent extracted $\stackrel{\stackrel{2}{\perp}}{=}$ preparations of known RA-1 virus grown in suckling Swiss Webster mouse brains. Since these preparations could not be rendered free of contaminating mouse molecular species by any of the several methods attempted, the resultant antisera always contained considerable cross reactivity with mouse and human sera and required extensive absorption 3 . procedures (see below). All immunisations and $\varrho$ bleedings were kindly performed in the laboratories of B Anderson, PhD (Northwestern University, 을 USA). Rabbits were immunised with 100-200 $\mu$ l of the virus extract, containing in each case $10^{6}-10^{7}$ 을 lethal mouse units $/ \mathrm{ml}$. The animals were given multiple site injections, including the subcutaneous, or intraperitoneal, and intramuscular routes. Booster injections were given at two to three week intervals, N్ల and the animals bled seven to 10 days after each injection. The initial immunisation employed the virus extract plus complete Freund's adjuvant; subsequent boosters were given in incompletes Freund's adjuvant. The antisera were standardised against virus and control mouse brain extracts, andō absorbed with gluteraldehyde cross linked mouse and human sera to the point of absent reactivity with human and mouse immunoglobulins and albumin (by Ouchterlony testing). 
Table 1 Electron microscopic analysis and reactivity to anti-RA-1 and anti-B19 antisera of isolates prepared directly from $R A$ and $O A$ synovia

\begin{tabular}{lll}
\hline & \multicolumn{2}{l}{ Incidence of positivity } \\
\cline { 2 - 3 } & $R A$ isolates & $O A$ isolates \\
\hline 10 nm particles & $11 / 13$ & $0 / 8$ \\
Anti-RA-1 reactivity & $6 / 11$ & $0 / 6$ \\
Anti-B19 reactivity (CIE) & $0 / 6$ & $0 / 4$ \\
Anti-B19 reactivity (RIA) & $0 / 3$ & $0 / 2$ \\
\hline
\end{tabular}

Table 2 EM analysis and reactivity to anti-RA-I antisera of isolates prepared from $R A$ and $\dot{O}$ A synovial cell cultures

\begin{tabular}{lll}
\hline & \multicolumn{2}{l}{ Incidence of positivity } \\
\cline { 2 - 3 } & $R A$ isolates & $O A$ isolates \\
\hline $10 \mathrm{~nm}$ particles & $6 / 6$ & $0 / 4$ \\
Anti-RA-1 reactivity & $6 / 6$ & $0 / 4$ \\
\hline
\end{tabular}

ASSAY FOR THE DETECTION OF FERRITIN IN THE ISOLATES

Rabbit antibody to human spleen ferritin (prepared by Calbiochem) was used in an ELISA assay with several of the isolates from rheumatoid and osteoarthritis synovial membranes. Briefly, microtitre plates were coated with the isolates and human serum (to serve as a positive control). The rabbit antiferritin antibody was applied in serial dilutions starting at 1:2. This was followed by the alkaline phosphatase conjugated goat antirabbit serum and finally, by the enzyme substrate.

\section{Results}

\section{ELECTRON MICROSCOPY STUDIES}

Virus-like particles were not seen in ultrathin tissue sections prepared from five rheumatoid synovial membranes. When negative staining was performed on the RA isolates large numbers of $10 \mathrm{~nm}$ particles were apparent in 11 of 13 preparations tested (Table 1). Most of these particles were circular and appeared to be empty (Fig. 2). Such particles were not present in isolates prepared from six OA synovial membranes. Although the morphology of these particles resembled ferritin, they did not react with an antiferritin antiserum in an ELISA assay. At no stage of the investigation were particles of a size similar to that of the parvovirus $(25 \mathrm{~nm})$ identified.

REACTIVITY OF ISOLATES WITH ANTI-RA-1 AND ANTI-B19 VIRUS ANTISERA

Six of 11 RA isolates reacted with the anti-RA-1 antiserum in contrast with none of the six OA preparations (Table 1). All of the positive RA isolates were enriched in $10 \mathrm{~nm}$ particles. To determine if any of the preparations contained B19 virus associated material the rheumatoid and $\mathrm{OA}$

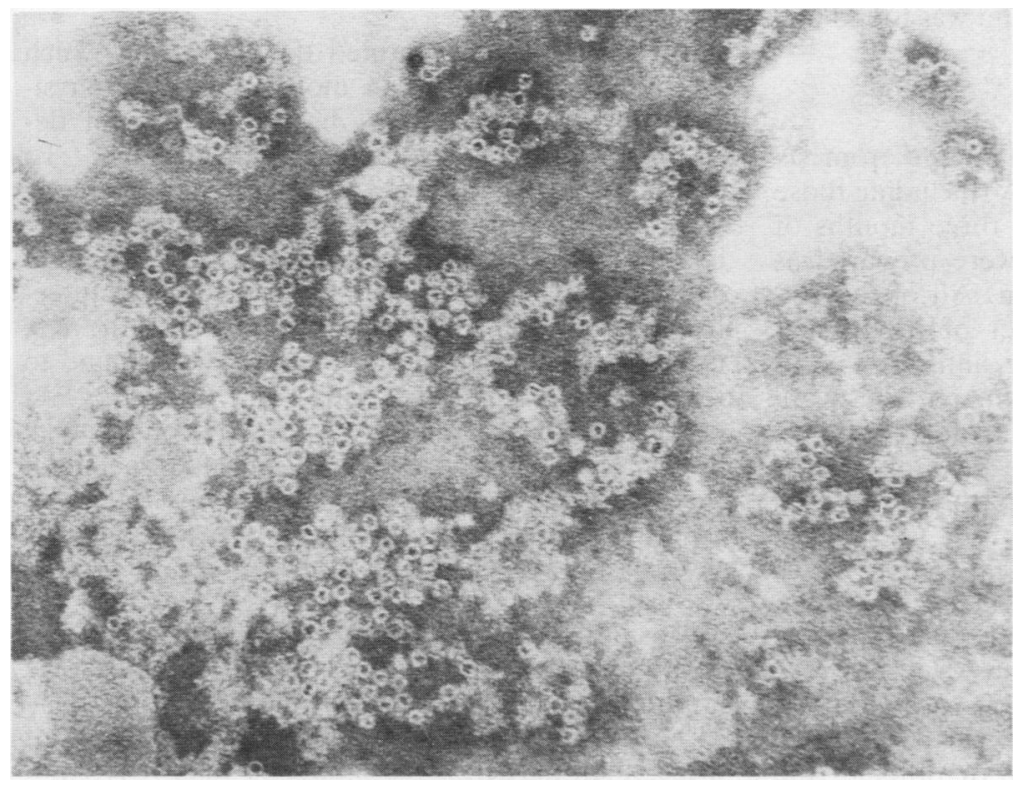

Fig. 2 Particles $(10 \mathrm{~nm})$, most of which were empty, but some gave the impression of being filled. These particies could be demonstrated readily and constantly in isolates derived from $R A$ membranes but not in isolates from $O A$ membranes. 


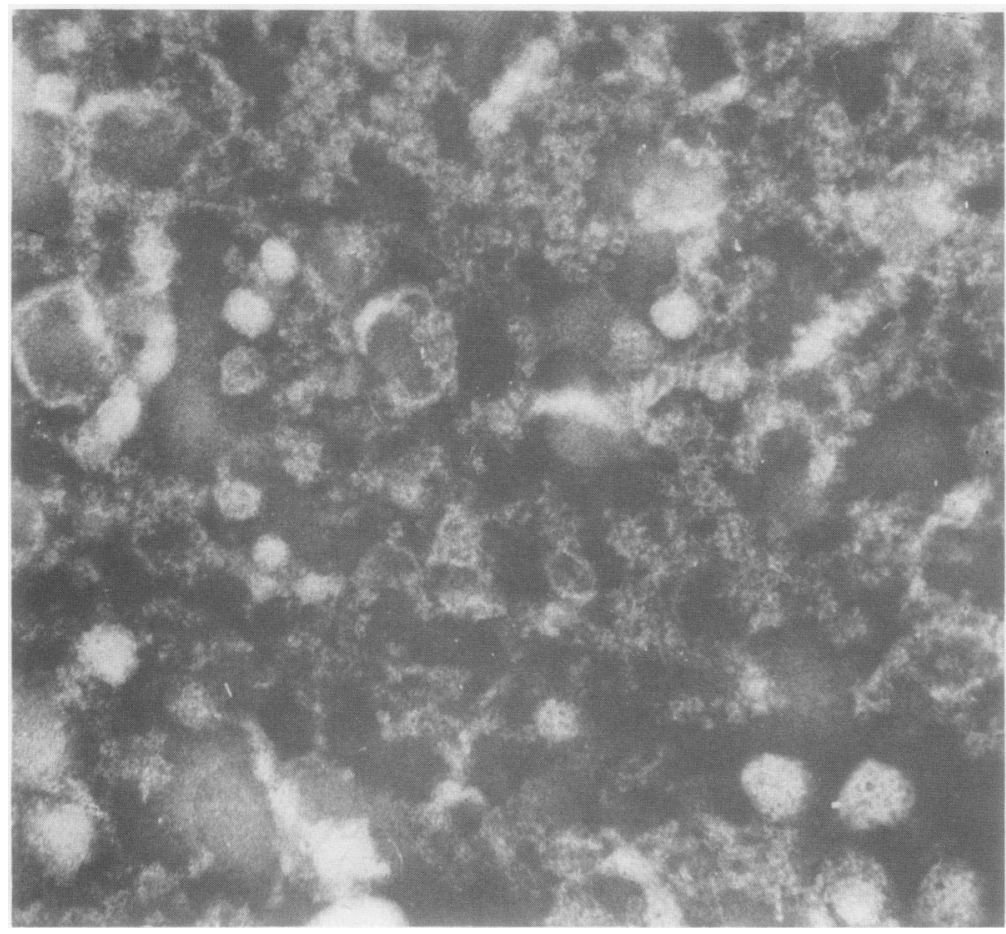

Fig. 3 Particles $(24 \mathrm{~nm})$, which could be found in two $R A$ membrane isolates. The size of these particles was not constant and the electron microscopic appearance not totally typical for virions.

isolates were tested for reactivity with a polyclonal and monoclonal anti-B19 virus antibody. From Table 1 it can be seen that all isolates tested did not react with either antiserum. Moreover, in other experiments the anti-RA-1 antiserum was found not to react with the $\mathrm{B} 19$ virus.

\section{SYNOVIAL CELL CULTURES}

Cultures of synovial cells were prepared from six patients with RA and four with OA (including those received from New York). After three months of culture (12 subcultures) isolates were prepared as described in the 'Methods' section. All of the RA isolates contained a large number of the $10 \mathrm{~nm}$ particles and all reacted with the anti-RA-1 antiserum (Table 2). Furthermore, $24 \mathrm{~nm}$ particles were found in two of the RA preparations (Fig. 3), but as their morphology was not totally typical for virions, it would seem unlikely that these particles were the RA-1 virus.

Since the replication of certain parvoviruses increases in the presence of a helper virus, an experiment was designed in which synovial cells from one patient with RA and one with OA were cocultured with either adenovirus, herpes virus, an enriched preparation of $10 \mathrm{~nm}$ particles, or a combination of particles with one or other of the viruses. In none of the isolates prepared from such cultures could $24 \mathrm{~nm}$ particles be demonstrated.

\section{Discussion}

An infectious agent, termed the RA-1 and which resembles parvoviruses in morphology and physi-응 cochemical characteristics, has recently been de-3. rived from cultured rheumatoid synovial cells. ${ }^{12}$ To determine if the RA-1 virus could be directly identified in RA synovium, fractions of homogen-o ised synovial tissue were prepared, at a caesium? chloride density which approximated that of infec $=0$ tive parvoviruses. Approximately $50 \%$ of the $\mathrm{RA}$. isolates and none of the OA isolates were found toor react with an anti-RA-1 antiserum. From the EMN demonstration that the RA-1 positive isolates weren devoid of complete virus particles it would seem that ${ }^{\omega}$ the anti-RA-1 antiserum is either reacting with determinants present on subunit structures of the? virus or cross reacting with other material present inos the isolates.

Most of the RA fractions and all of the RA- $1 \frac{0}{0}$ positive lysates were enriched in particles whose size $\vec{D}$ $(10 \mathrm{~nm})$ was smaller than that of parvoviruses $\left(24-\frac{?}{0}\right.$ $25 \mathrm{~nm}$ ). At first we thought that the morphology of $\varrho$ these small particles was similar to that of ferritin 
Careful examination of the electron micrographs by colleagues who work with ferritin showed that the particles do not form the four-particle lattices which are typical for this molecule in human tissue. Furthermore, isolates enriched with particles did not react with an antiferritin antiserum, and the demonstration that some of the particles are empty and others electron dense does not suggest the presence of ferritin. Although the appearance of these particles also resembles that of negatively stained preparations of human $\mathrm{C}$ reactive proteins and human serum amyloid $\mathrm{P}$ component, ${ }^{\gamma}$ it is unlıkely that the particles are of either of these proteins or ferritin since they were also present in isolates prepared from RA synoviocytes which had been cultured for three months.

The first identification of parvovirus-like particles in man was during the screening of symptom free donors for hepatitis B surface antigen. 'The human parvovirus (HPV), also called the B19 virus, is responsible for febrile illness in haematologically normal people, ${ }^{10}$ and aplastic crisis in patients with chronic haemolytic anaemia. ${ }^{11} 12$ An arthropathy induced by HPV has recently been described, ${ }^{3}$ and epidemiological studies suggest that polyarthropathy may be a clinical manifestation of HPV infection in man. ${ }^{34}$ The reactivity of most of the RA isolates with the anti-RA-1 antiserum appears to be unrelated to any involvement of the $\mathrm{B} 19$ virus since this virus and all of the RA-1 positive isolates did not react with the anti-RA-1 antiserum. If parvovirus, which is an attractive candidate for the induction of polyarthropathy, ${ }^{14}$ is present in synovial tissue then it is likely to be in a form distinct from that of other known parvoviruses. Support for this view comes from the finding that endonuclease mapping of the RA-1 DNA has shown it to be unique among the published human and animal parvoviruses ( $\mathrm{R}$ W Simpson, personal communication).

Our inability to induce the appearance of parvovirus in synovial cells infected with adenovirus may be related to the known difficulties in demonstrating or growing parvovirus in culture, as illustrated by the animal parvoviruses which because of their limited DNA available for replication are extremely specific in their cell culture requirements. ${ }^{15}$ The reactivity of the RA isolates with the anti-RA-1 antiserum is probably not due to the complete virus particles, but to the $10 \mathrm{~nm}$ particles or free virus antigen in the preparations. The nature of these $10 \mathrm{~nm}$ particles, their relation with RA-1, and their pathogenetic significance, if any, are the subjects of future study.

\section{References}

1 Simpson R W. McGinty L, Simon L. Smith C A, Godzeski C W. Boyd R J. Association of parvoviruses with rheumatoid arthritis of humans. Science 1984: 223: 1425-8.

2 Smith C A, Craig R. Anderson B. Detection of parvovirus antigen in cultured rheumatoid synovial cells. Arthritis Rheum 1986: 29 (suppl): A16.

3 Reid D M. Reid T M W. Brown T, Rennie J A N, Eastmond C J. Human parvovirus-associated arthritis: a clinical and laboratory description. Lancet 1985: i: 422-5.

4 White D G. Woolf A D, Mortimer P P, Cohen B J, Blake D R, Bacon P A. Human parvovirus arthropathy. Lancet 1985; i: 419-21.

5 Tattersall P. Ward D. In: Ward D. Tattersall P, eds. The parvoviruses - an introduction to replication of mammalian parvoviruses. USA: Cold Spring Harbor Lab. 1978: 3-12.

6 Ropes M W. Bennet G A. Cob S. Jacox R. Jesser R A. Revision of diagnostic criteria for rheumatoid arthritis. Bull Rheum Dis 1958: 9: 175-6.

7 Dayer I M. Krone S M. Russell R G G. Robinson D R. Production of collagenase and prostaglandins by isolated adherent rheumatoid synovial cells. Proc Natl Acad Sci USA 1976; 73: 945-9.

8 Pepys M B. C-reactive protein and the acute phase response. Immunol Today 1982; 3: 27.

9 Cossart Y E. Field A M. Cant B. Widdows D. Parvovirus-like particles in human sera. Lancet 1975; i: 72-3.

10 Anderson M J, Jones S E, Fisher-Hoch S P, et al. Human parvovirus, the cause of erythema infectiosum. Lancet 1983; i: 1378.

11 Pattison J R, Jones S E. Hodgson I, et al. Parvovirus infections and hypoplastic crises in sickle-cell anaemia. Lancet 1981; i: 664-5.

12 Young N S, Mortimer P, Moore J G, Humphries R K. Characterization of a virus that causes transient aplastic crisis. J Clin Invest 1984; 73: 224-30.

13 Dougados M. Amor B, Lefrere J J, Couvouce A M. Human parvovirus arthropathy. Arthritis Rheum 1986; 29: 575-6.

14 Brown K A. Rheumatoid arthritis: another viral candidate. Nature 1984; 309: 582.

15 Summers J, Jones S E, Anderson M J. Characterisation of the genome of the agent of erythrocyte aplasia permits its classification as a human parvovirus. J Gen Virol 1983; 64: 2527-32. 